\title{
Targeted temperature management for postcardiac arrest syndrome
}

\section{Care}

\section{REVIEW ARTICLE}

\author{
Yasuhiro Kuroda, MD'; Kenya Kawakita, $\mathrm{MD}^{2}$ \\ 'Department of Emergency, Disaster, and Critical Care Medicine, Faculty of Medicine, Kagawa \\ University, Kita, Japan \\ ${ }^{2}$ Emergency Medical Center, Kagawa University Hospital, Faculty of Medicine, Kagawa University, \\ Kita, Japan
}

Received: January 16, 2020

Revised: March 20, 2020

Accepted: March 25, 2020

Corresponding Author:

Yasuhiro Kuroda

Department of Emergency, Disaster, and Critical Care Medicine, Faculty of Medicine, Kagawa University, 1750-1 Ikenobe, Miki, Kita-gun 761-0793, Japan

Tel: +81-87-891-2392

Fax: +81-87-891-2393

E-mail: kuroday@kms.ac.jp

Neurocritical care management to improve neurologic outcome for postcardiac arrest syndrome (PCAS) has focused considerably on targeted temperature management (TM). TM attenuates the destructive processes following ischemia/reperfusion in PCAS. The principal indication of TM is a patient with sustained coma after return of spontaneous circulation (ROSC). TM can be strongly recommended with a target temperature between $32^{\circ} \mathrm{C}$ and $36^{\circ} \mathrm{C}$ for patients with shockable rhythm and out-of-hospital cardiac arrest (OHCA) and weakly recommended for patients with initial asystole or pulseless electrical activity with OHCA and those with in-hospital cardiac arrest. TM is induced and maintained using a cooling device with body temperature feedback under appropriate analgosedation. It requires the intensive management of various systemic respiratory, circulatory, and metabolic parameters that control shivering to prevent secondary brain damage. Considering the cerebral perfusion pressure, it is suggested that the mean arterial pressure should be particularly maintained over $80 \mathrm{~mm} \mathrm{Hg}$. Seizure management, including continuous electroencephalography monitoring, is also needed. Finally, we must continue the above mentioned care during and after the rewarming phase, because high fever and shivering may appear again during this period. Furthermore, neurological prognostication should be performed at least 72 hours after ROSC through clinical investigations and multimodal testing without sedation.

Keywords: Hypothermia, induced; Critical care; Neurology; Shivering; Brain injuries

\section{INTRODUCTION}

Targeted temperature management (TTM) is a clinical treatment strategy to control core body temperature (target temperature) for a certain duration to reduce secondary brain injury. Fig. 1 shows the general definition of antihyperthermia, therapeutic normothermia, and therapeutic hypothermia. Generally, thera- peutic hypothermia is defined as a core body temperature of $32^{\circ} \mathrm{C}$ to $34^{\circ} \mathrm{C}$ (TTM $32^{\circ} \mathrm{C}$ to $34^{\circ} \mathrm{C}$ ) using various methods. It is important to know that therapeutic normothermia, which involves maintaining a core body temperature of $36^{\circ} \mathrm{C}$ to $37^{\circ} \mathrm{C}$ (TTM $36^{\circ} \mathrm{C}$ to $37^{\circ} \mathrm{C}$ ) using various methods, is different from no cooling or normothermia. Therefore, it is more appropriate to use the terms TTM $32^{\circ} \mathrm{C}$ to $34^{\circ} \mathrm{C}$ or TTM $36^{\circ} \mathrm{C}$ instead of therapeutic

(C) 2020 The Korean Neurocritical Care Society

This is an Open Access article distributed under the terms of the Creative Commons Attribution Non-Commercial License (http://creativecommons.org/licenses/by-nc/4.0/) which permits unrestricted noncommercial use, distribution, and reproduction in any medium, provided the original work is properly cited. 


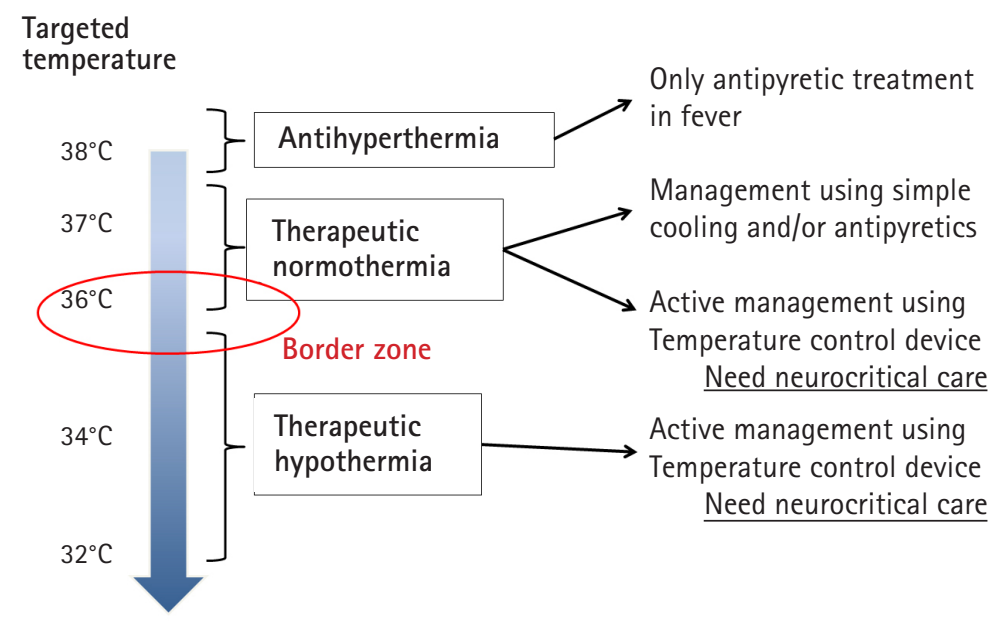

Fig. 1. Definition of targeted temperature management.

hypothermia or normothermia, respectively.

The destructive processes following ischemia/reperfusion in postcardiac arrest syndrome (PCAS) are divided into primary injury and secondary injury $[1,2]$. Primary injury begins immediately after cardiac arrest and is caused by cessation of cerebral blood flow (CBF). As cerebral oxygen delivery decreases, adenosine triphosphate (ATP) production stops, causing energy-dependent ion pump dysfunction. Intracellular $\mathrm{Na}+$ accumulation results in cytotoxic edema, and depletion of ATP leads to anaerobic metabolism, cerebral lactate accumulation, and intracellular acidosis. Cellular ischemia causes influx of $\mathrm{Ca}^{2+}$ into cells, which activates lytic enzymes and mitochondrial injury, further depleting ATP. Excitatory neurotransmitter release activates lipases and proteases, causing apoptosis.

Secondary injury begins immediately after return of spontaneous circulation (ROSC) and takes place in the hours and days following cardiac arrest. After ROSC, reperfusion injury causes neuronal damage despite restoration of cerebral oxygen delivery. An initial period of cerebral hyperemia is followed by hypoperfusion, resulting in a "no-reflow" state that exacerbates secondary injury. The reason for "no-reflow" is microcirculatory dysfunction and/or impaired vasomotor regulation caused by microthrombi, decreased nitric oxide production, and increased intravascular viscosity due to extravasation of intravascular water (blood brain barrier disruption). Free radical release, glutamate production, and intracellular $\mathrm{Ca}^{2+}$ accumulation also leads to reperfusion injury and/or microcirculatory dysfunction.

These primary and secondary mechanisms are all stimulated by fever. Many observational studies have reported that fever after ROSC was related to poor neurological outcomes $[3,4]$. In the no control of TTM scenario, almost all patients will develop a fever early after ROSC $[5,6]$. Both mechanisms are also inhibit- ed by hypothermia. Reduction in core temperature decreases the cerebral metabolic rate of oxygen $\left(\mathrm{CMRo}_{2}\right)$ and attenuates several intracellular pathways involved in secondary brain damage which occur in the minutes and days after collapse [1]. For TTM, active temperature control, shivering prevention, and intensive care unit (ICU) bundle care are needed, regardless of the selected targeted temperature. TTM to prevent fever is reasonable for neuroprotection.

\section{EVIDENCE FOR TTM}

\section{For out-of-hospital cardiac arrest patients with shockable rhythm}

TTM significantly improved neurologic outcomes in patients with PCAS of suspected cardiac origin who were treated under bundle care (Table 1) [5-7]. In 2002, a landmark study on TTM was published, which indicated that therapeutic hypothermia (TTM $32^{\circ} \mathrm{C}$ to $34^{\circ} \mathrm{C}, 24$ hours cooling and 8 hours rewarming) resulted in better neurological outcomes at 6 months when compared to the outcomes without fever control in patients with out-of-hospital cardiac arrest (OHCA) due to an initial shockable rhythm [5]. In the same year, Bernard et al. [6] also showed that therapeutic hypothermia (TTM $33^{\circ} \mathrm{C}, 12$ hours cooling and 6 hours rewarming) increased the proportion of patients with OHCA due to an initial shockable rhythm and of patients who could return home or participate in rehabilitation at discharge when compared to the outcomes without fever control. These two studies allowed managing physicians to make better decisions regarding prognostication and withdrawal of life-sustaining therapies. Another landmark study on TTM (the TTM trial) published in 2013 showed that TTM $\left(36^{\circ} \mathrm{C}, 24\right.$ hours, followed by 8 hours of rewarming to $37^{\circ} \mathrm{C}$ and temperature maintenance below 
Table 1. Representative studies of TTM for shockable patients with out-of-hospital cardiac arrest

\begin{tabular}{|c|c|c|c|c|c|c|c|}
\hline \multirow{3}{*}{$\begin{array}{l}\text { Research name } \\
\text { Study } \\
\text { Case no. }\end{array}$} & \multicolumn{2}{|r|}{ HACA } & \multicolumn{2}{|c|}{ TTM } & \multicolumn{2}{|c|}{ TाH } & \multirow{2}{*}{$\begin{array}{c}\text { J-PULSE-HYPO } \\
\text { Yokoyama et al. (2011) [10] }\end{array}$} \\
\hline & \multicolumn{2}{|c|}{ Holzer et al. (2002) [5] } & \multicolumn{2}{|c|}{ Nielsen et al. (2013) [8] } & \multicolumn{2}{|c|}{ Kirkegaard et al. (2017) [7] } & \\
\hline & 137 & 138 & 473 & 466 & 176 & 175 & 452 \\
\hline Initial rhythm VF/VT (\%) & 97 & 96 & 79 & 81 & 86 & 91 & 69 \\
\hline Archive to target temperature ( $\mathrm{hr}$ ) & $8(4-16)$ & - & $4-8$ & $4-8$ & 4 & 4 & 3 \\
\hline Target temperature $\left({ }^{\circ} \mathrm{C}\right)$ & $32-34$ & 37.5 (no control) & 33 & 36 & 33 & 33 & 33.9 \\
\hline Target variation $\left({ }^{\circ} \mathrm{C}\right)(2 \mathrm{SD})$ & $0.5-1.0$ & 0.5 (25 percentile) & $1.5-3.2[83]$ & $1.5-2.2[83]$ & $1.0-1.5$ & $1.0-1.5$ & - \\
\hline TTM maintenance duration (hr) & 24 & 24 & 24 & 24 & 24 & 48 & 24 \\
\hline Rewarming speed & Passive & - & $0.5 \mathrm{c} / \mathrm{hr}$ & $0.5 \mathrm{c} / \mathrm{hr}$ & - & - & - \\
\hline Total TTM duration (hr) & $32(24+8)$ & & 72 & 72 & & & \\
\hline Intravascular device (\%) & 0 & & 26 & [83] & 59 & 65 & 48 \\
\hline Infection (\%) & 50 & 36 & 56 [82] & 51 [82] & 43 & 49 & 13 [21] \\
\hline Good neurologic outcome (\%) & 55 & 39 & 46 & 48 & 64 & 69 & 55 \\
\hline Outcome decision after collapse & 6 months & & 6 months & & 6 months & & 30 days \\
\hline
\end{tabular}

HACA, hypothermia after cardiac arrest; TMM, targeted temperature management; TH, time-differentiated therapeutic hypothermia; J-PULSE-HYPO, japanese population-based utstein-style study with defibrillation and basic/advanced life support education and implementation-hypothermia; VF, ventricular fibrillation; $\mathrm{VT}$, ventricular tachycardia; SD, standard deviation.

$37.5^{\circ} \mathrm{C}$ until 72 hours) was as effective (in terms of primary outcome and mortality) as therapeutic hypothermia $\left(32^{\circ} \mathrm{C}\right.$ to $\left.34^{\circ} \mathrm{C}\right)$ and is an acceptable alternative to it [8]. Nevertheless, it is important to confirm the findings of the TTM trial, in which $80 \%$ of patients had ventricular fibrillation $(\mathrm{VF}) /$ ventricular tachycardia (VT) and 20\% did not have VF/VT (pulseless electrical activity $[\mathrm{PEA}]$ /asystole), as the severity of brain injury might have been high (Table 1). In the TTM trial, providing a defined prognostication protocol resulted in a longer observation period. Lopez-deSa et al. [9] compared the temperatures of $32^{\circ} \mathrm{C}$ and $34^{\circ} \mathrm{C}$ for therapeutic hypothermia ( 24 hours) and reported that there was no significant difference in patient independence at 6 months. A multicenter registry in Japan enrolled 452 adult patients (shockable rhythm, 68.9\%) undergoing therapeutic hypothermia $\left(33.9^{\circ} \mathrm{C} \pm 0.4^{\circ} \mathrm{C}\right)$ and showed that the proportion of patients with favorable neurologic outcome was $55.3 \%$ at 30 days after cardiac arrest [10]. These data support the use of temperature control. The International Liaison Committee on Resuscitation (ILCOR), American Heart Association (AHA), and American Academy of Neurology (AAN) recommend TTM at a target temperature between $32^{\circ} \mathrm{C}$ to $36^{\circ} \mathrm{C}$ for patients with OHCA due to shockable rhythm [11-13].

Although Deye et al. [14] reported that a target temperature between $32 \%$ to $34^{\circ} \mathrm{C}$ remained unchanged for $56 \%$ respondents in 2016 after TTM trial, the use of therapeutic hypothermia decreased in a United States registry of patients with OHCA reported in 2018 [15].

\section{For OHCA patients with nonshockable rhythm}

Regarding a nonshockable rhythm (PEA/asystole), the TTM trial presented data showing that there was no significant difference in death rates between patients who underwent therapeutic hypothermia $\left(32^{\circ} \mathrm{C}\right.$ to $\left.34^{\circ} \mathrm{C}\right)$ or no therapeutic hypothermia $\left(36^{\circ} \mathrm{C}\right)$ [8]. Other studies show an association between therapeutic hypothermia and favorable outcome [16-20] or survival [16,18]. In Japan, Soga et al. [21] reported that post-ROSC cooling is an effective treatment for patients with nonshockable cardiac arrest when the time interval from collapse to ROSC is short. TTM $32^{\circ} \mathrm{C}$ to $36^{\circ} \mathrm{C}$ for patients with initial asystole or PEA is also supported by the AHA, ILCOR, and AAN guideline [11-13]. Regarding TTM for nonshockable rhythm PCAS, the first large randomized control trial was published recently Therapeutic Hypothermia after Cardiac Arrest in Nonshockable Rhythm (HYPERION) [22]. In this French trial, 581 adult patients who were comatose after resuscitation from either an in-hospital cardiac arrest (IHCA) or OHCA with an initial nonshockable rhythm were randomized to either TTM $33^{\circ} \mathrm{C}$ or TTM $37^{\circ} \mathrm{C}$, both for 24 hours. At 90 days, 29 of 284 patients $(10.2 \%)$ in the $33^{\circ} \mathrm{C}$ group were alive with a cerebral performance category of 1 or 2 , as compared with 17 of 297 (5.7\%) in the normothermia group (risk difference, 4.5\%; 95\% confidence interval, 0.1 to $8.9 ; P=0.04$ ). This trial reinforces the recommendation of considering TTM $32^{\circ} \mathrm{C}$ to $36^{\circ} \mathrm{C}$ for PCAS patients with nonshockable rhythm. Patients with nonshockable rhythm tend to have numerous noncardiac issues and higher mortality than those in VF/VT [23]. Further studies are needed to determine the role of TTM in this patient population. 


\section{For IHCA patients}

For patients with IHCA, the Guidelines-Resuscitation database suggested poor outcome (regarding survival to hospital discharge and neurologic outcome) with TTM [24]. A potential selection bias, however, should be pointed out while interpreting this data. According to the current guidelines, TTM should be considered for patients with IHCA [11-13]. We must also await further studies.

\section{INCLUSION AND EXCLUSION CRITERIA FOR TTM}

TTM is recommended for adult patients in a coma (Glasgow Coma Scale $[\mathrm{GCS}] \leq 8$ and $\mathrm{E}=1$ and $\mathrm{V}=1$ or 2 and $\mathrm{M} \leq 5$ ) after ROSC, irrespective of an initial cardiac rhythm, although patients with OHCA due to a shockable rhythm are expected to show better outcomes than those with nonshockable rhythm (Fig. 2). TTM is also considered to be performed in patients with OHCA due to nonshockable rhythm or in patients with IHCA. The most important consideration in a TTM operation is adequate neurocritical care with TTM.

If patient consciousness level has recovered rapidly recovered and they are able to follow verbal commands (GCS motor score $=6$ ), TTM is not recommended. Although a patient with GCS motor score 5 is reported to not be a candidate for TTM in one study [25], further research is needed to determine whether GCS motor score 5 is a suitable threshold for patients to not be candidates for TTM. TTM is not indicated for patients who have a preexisting illness that precludes meaningful recovery or those considering a do-not-resuscitate order. Other contraindications are shown in Fig. 2. Finally, if the time interval between cardiac arrest and TTM initiation is long, the neuroprotective effect of TTM may be limited. Practically, this means that TTM is not applied for cardiac arrest patients 12 hours after collapse [26].

\section{TEMPERATURE SELECTION: CONSIDERING $36^{\circ} \mathrm{C}$}

Therapeutic hypothermia (TTM $32^{\circ} \mathrm{C}$ to $34^{\circ} \mathrm{C}$ ), which protects secondary brain injury more as compared to TTM $36^{\circ} \mathrm{C}$, may produce coagulopathy and bleeding. If the patient has surgical bleeding, intracranial bleeding, hemorrhagic diathesis, or trauma, TTM $36^{\circ} \mathrm{C}$ should be considered, because it usually does not

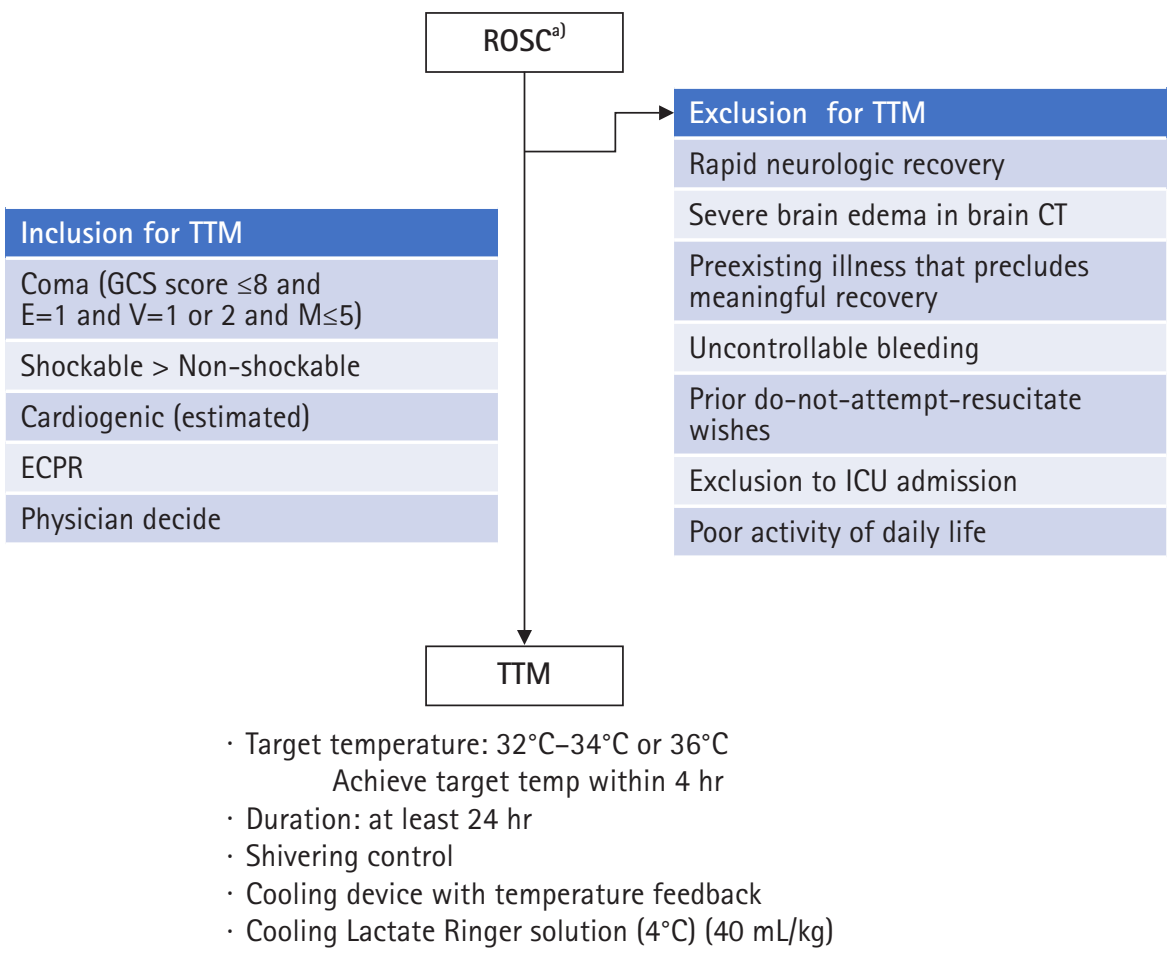

Fig. 2. Special considerations before and during targeted temperature management (TMM) induction. ROSC, return of spontaneous circulation; GCS, Glasgow Coma Scale; ECPR, extracorporeal cardiopulmonary resuscitation; CT, computed tomography; ICU, intensive care unit. ${ }^{\text {a) }}$ Coronary angiography with percutaneous coronary intervention for ST-elevated myocardial infarction. 
cause coagulopathy. Finally, TTM $36^{\circ} \mathrm{C}$ using an intravascular cooling device can be performed in the rare cases of patients who have cold agglutinins (usually activated only below $31^{\circ} \mathrm{C}$ ).

For circulatory management, compared to TTM $36^{\circ} \mathrm{C}$, TTM $32^{\circ} \mathrm{C}$ to $34^{\circ} \mathrm{C}$ may result in more hemodynamic instability [27] that may require vasopressor support.

\section{INDUCTION OF TTM}

For patients eligible for TTM, tracheal intubation and monitoring of several aspects, including circulation, respiration, and metabolism, should be performed. Core body temperature is monitored using a bladder, endovascular, or esophageal probe.

If the patient is eligible for TTM, it must be induced and target temperature must be reached as soon as possible (Fig. 2). Table 1 shows longer time intervals to achieve targeted temperature, especially in Hypothermia after Cardiac Arrest Study Group study [5], possibly because cooling devices with temperature feedback were not used. Stanger et al. [28] reported that initiation of TTM (door-to-TTM) within 122 minutes of hospital admission was associated with improved survival. Care must be taken to control the time interval between collapse and ROSC, because this interval might determine the outcome.

In patients with cardiac failure, TTM should be induced under extracorporeal cardiopulmonary resuscitation (ECPR) which can manage core body temperature. If the patient does not have accompanying left ventricular dysfunction, TTM is induced using a temperature control device (endovascular, surface, intranasal, or esophageal cooling) with automated feedback temperature control through continuous input of the patient's core temperature [29]. Recent studies show rapid achievement of target temperatures using temperature control devices and shivering management.

Rapid infusion of cold $\left(4^{\circ} \mathrm{C}\right)$ lactated Ringer infusion $(40 \mathrm{~mL} / \mathrm{kg})$ decreases the core body temperature by $1^{\circ} \mathrm{C}$ for each liter $[30,31]$ in the emergency room and/or ICU. However, prehospital use of cold fluids increases the risk of rearrest and pulmonary edema [32]. Shivering control and analgosedation is needed for rapid induction of TTM, regardless of targeted temperature with/ without ECPR.

\section{EXTRACORPOREAL CARDIOPULMONARY RESUSCITATION}

Among patients without ROSC but with good neurological indicators (shockable rhythm, short time interval between collapse and ROSC), ECPR is an option for resuscitation. Ortega-Debal- lon et al. [33] reviewed several cohort studies and reported that the overall survival rate with ECPR was $20 \%$ among patients without ROSC; however, the survival rate is known to vary among studies. In Japan, the Study of Advanced Cardiac Life Support for Ventricular Fibrillation with Extracorporeal Circulation in Japan (SAVE-J) study reported that among OHCA patients with a shockable rhythm on initial electrocardiography, the rate of good neurological outcomes (11.2\%) at 6 months after insult was higher with treatment including ECPR, therapeutic hypothermia, and intraaortic balloon pump (IABP) than with treatment not involving ECPR (2.6\%) [34]. Thus, ECPR is a good approach for resuscitation in selected patients.

One study revealed that IABP with percutaneous coronary intervention (PCI) contributed to improved neurologic outcome under cardiogenic shock after ROSC [35]. Another study revealed that ECPR in addition to PCI improved neurologic outcome in patients who failed to respond to conventional CPR if the collapse-to-bypass interval was less than 55.5 minutes [36]. IABP or ECPR may be considered in patients for whom the cause of cardiac arrest is suspected to be reversible.

Furthermore, cardiogenic shock should not be a reason to avoid TTM, and TTM before and/or during acute PCI is not a contraindication. Practically, if TTM has already been started before PCI, possible complications (low blood pressure and/or hypopotassemia due to massive urination, etc.) must be checked and treated even in catheter laboratory (see heading: circulatory care, electrolyte management).

\section{TREATMENT FOR MYOCARDIAL DYSFUNCTION}

Acute coronary syndrome is a common cause of cardiac arrest, and treatment for revascularization is necessary. In patients with ST-segment elevation or left bundle branch block on initial electrocardiography after ROSC, the prevalence of an acute coronary lesion is more than $80 \%$ [37]. If the cause of cardiac arrest is ST-elevation acute myocardial infarction (STEMI), immediate coronary angiography (CAG) with/without PCI is recommended. Even for non-STEMI that induces cardiac arrest, CAG with/ without PCI is recommended, because prehospital electrocardiography does not identify an occluded coronary artery [38], and a previous study found that $25 \%$ of patients with non-STEMI had an occluded coronary artery [39]. Although Lemkes et al. [40] recently reported that a strategy involving immediate CAG was not found to be better than delayed CAG for PCAS patients who had no signs of STEMI, the relatively lower severity of the patients included was pointed out as a research limitation [41]. Further 
study is needed regarding necessity of emergency CAG.

Reperfusion injury, in addition to ischemic insult, is a main cause of myocardial dysfunction. Many studies indicate that PCI improves survival or neurologic outcome $[42,43]$. Some studies have demonstrated that better survival and functional outcome is achieved after ROSC with a combination of TTM and PCI for STEMI $[44,45]$. In one randomized controlled trial and analysis that did not involve cardiac arrest patients, this combination reduced the size of the cardiac muscle ischemic lesion in case hypothermia was achieved before reperfusion of the coronary artery $[46,47]$. Clinical research reported that TTM (lower core temperature) before PCI can decrease the severity of myocardial infarction and might improve cardiac function after ROSC [48]. Studies of survival or neurologic outcome of emergency PCI for non-STEMI are inconsistent; some investigators did not find it helpful [49], but others reported favorable resolutions [42,43,45,50].

\section{SHIVERING CONTROL}

Shivering is a physiologic homeostatic mechanism to maintain body temperature and is usually initiated at approximately $36^{\circ} \mathrm{C}$ [51]. Shivering is severe at $\mathrm{TTM} 36^{\circ} \mathrm{C}$ due to the patient thermoregulatory defenses, which are partly suppressed at $32^{\circ} \mathrm{C}$ to $33^{\circ} \mathrm{C}$ $[1,30]$. One interesting report showed that shivering control and analgosedation use are difficult with TTM at $36^{\circ} \mathrm{C}$ [52]. Sustained shivering causes an increased metabolic rate and cardiac output, tachycardia, elevated blood pressure, increased lethal cardiac complications, increased carbon dioxide $\left(\mathrm{CO}_{2}\right)$ production, wound pain, increased $\mathrm{CMRo}_{2}$ and intracranial pressure (ICP) [53], and increased stress response. Shivering commonly occurs during TTM and may lead to failure to achieve or maintain adequate hypothermia. Therefore, the management of shivering, including its evaluation and treatment using adequate analgosedation, is important and necessary during TTM to preserve the cerebral oxygen demand/supply balance and strict temperature management.

Warning signs of shivering are goose bumps, masseter palpation, electrocardiography artifacts, difficulty in cooling, and temperature increase in spite of TTM. Shivering should be assessed using a subjective, simple, and reliable clinical scale such as the Bedside Shivering Assessment Scale every 1 hour in the ICU [53]. To suppress shivering and prevent prolonged sedation and paralysis, a stepwise antishivering protocol during TTM is recommended [29,54]. However, it does not necessarily need to be stepwise and depends on the intensity of shivering. In general, patients with PCAS who are comatose during TTM need tracheal intubation and therefore require sedation and analgesia. At initiation of hypothermia, skin counter-warming using nonpharmacologic methods should be considered even when surface cooling methods are used for TTM (Fig. 3) [55-57]. This involves the warming of the noncooled areas of the skin (i.e., the face, hands, feet) using a warm-air blanket even when surface cooling methods are used. Drug therapy should include magnesium sulfate, dexmedetomidine, remifentanil, fentanyl, meperidine, and scheduled acetaminophen. If shivering is still not controlled, propofol, midazolam, and finally neuromuscular blockade (NMB) may be initiated [54]. To suppress shivering, a combination of methods should be used, and shivering should be aggressively controlled. It is presumed that the combined use of NMB in addition to complete analgosedation to achieve rapid induction of TTM and NMB titration after achieving targeting temperature are an alternative method.

On the other hand, one study reported that patients with the most severe brain injuries have less shivering [58]. Other studies have shown that shorter time to target temperature is associated with poor neurologic outcome $[59,60]$. It is hypothesized that patients with more severe or irreversible neurologic damage are less reactive to low temperatures, so there is less shivering [60] and a reduced requirement for NMB [61]. The relationship between shivering and outcome has yet to be fully elucidated.

\section{ANALGOSEDATION}

Sedation may reduce secondary cerebral ischemia and decrease elevated ICP by reducing the $\mathrm{CMRo}_{2}, \mathrm{CBF}$, and cerebral blood volume (CBV) [62]. Sedation and analgesia also help control shivering and seizures, which is required for the induction and maintenance of TTM to reduce the risk of brain damage caused by seizures (Fig. 3).

On the other hand, sedation makes it difficult to perform an accurate neurologic examination and clinical assessment. After arrest, residual sedation or paralysis confounds the clinical examination [63]. One study showed that patients undergoing TTM $\left(\leq 33^{\circ} \mathrm{C}\right)$ recovered consciousness in a mean of 3.8 days, with approximately $20 \%$ awakening after 5 days postarrest [64]. Recently, Rey et al. [65] reported that increased utilization of midazolam during the TTM phase correlates with late awakening (median time to awakening 5 days; range, 3 to 23 days from sedation stop).

Early interruption of sedation during TTM causes shivering. In brain-injury patients, interruption of sedation causes increased ICP [66]. Therefore, a wake-up test should be avoided during the first 24 hours after ROSC [67]. It is suggested that the tapering of sedative infusions should not exceed $25 \%$ per day [ 51 ]. In patients at risk of brain edema or who have an elevated ICP, uncontrolled status epilepticus, or ongoing hypothermia, sedatives should not 


\section{Shivering control and analgosedation}

Mg sulfate $0.5 \mathrm{~g} / \mathrm{hr}$ (or $2 \mathrm{~g}$ slowly): target serum level 3-4 mg/dL

Surface counter warming using warming blanket and bandage (see photo)

and if necessary add acetaminophen $500 \mathrm{mg}$ every $4-6 \mathrm{hr}$
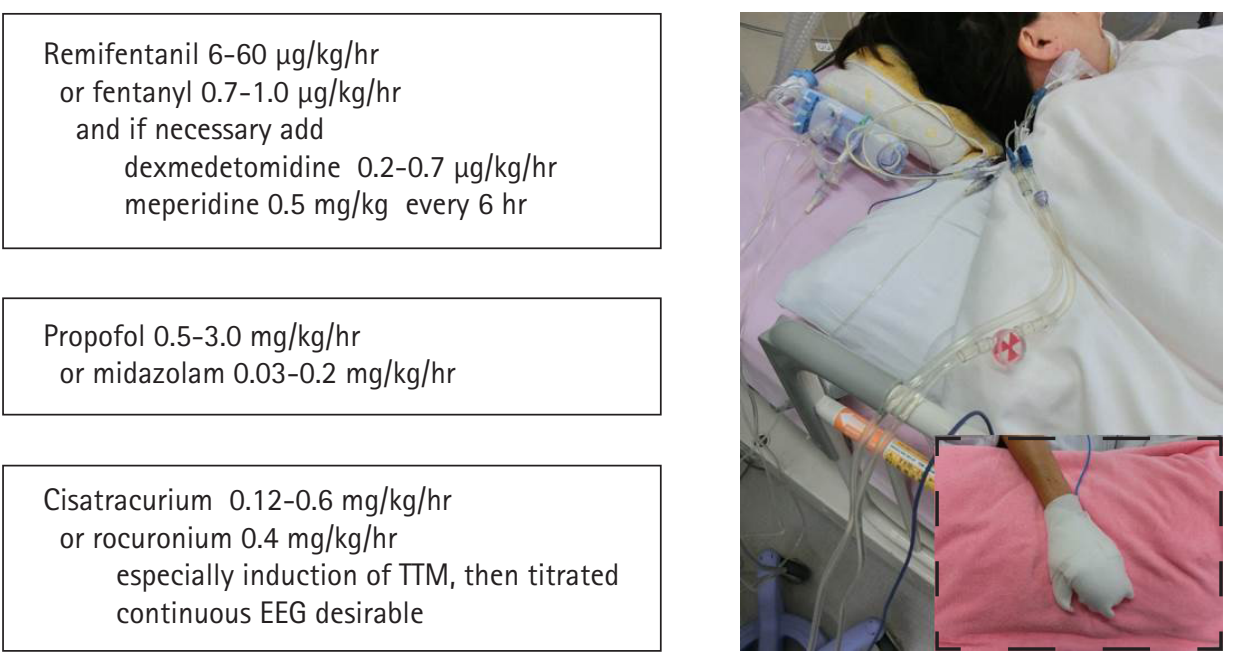

Shivering should be assessed every 1 hour using the BSAS.

Fig. 3. Shivering control and analgosedation. $T M$, targeted temperature management; $E E G$, electroencephalography; BSAS, bedside shivering assessment scale.

be abruptly discontinued. When weaning of sedation commences, attention should be paid to these risks with appropriate use of such tools as computed tomography, electroencephalography (EEG), and ICP monitoring.

\section{Drugs for TTM}

Propofol has a rapid onset and short duration of action which allows for meaningful neurologic examinations [68]. It is associated with a greater risk of hypotension with cerebral hypoperfusion than other drugs, as well as the risk of propofol infusion syndrome. Propofol significantly decreases CBV by causing vasoconstriction [69].

Midazolam results in less hemodynamic instability than propofol, but it prolongs the duration of mechanical ventilation and length of ICU stay [70]; furthermore, it may prolong the time to awakening and reduce the accuracy of the clinical examination, because the half-life of midazolam is prolonged by hypothermia $[65,71]$. During TTM, low continuous infusions of midazolam are preferred.

Dexmedetomidine is short-acting, provides mild to moderate sedation and analgesic effects, allows clinical assessment, and may be neuroprotective [72]. Dexmedetomidine directly lowers the shivering threshold by central alpha-2 agonism [73]. However, it frequently causes hypotension and bradycardia.

NMB is selectively administered during TTM, resulting in more rapid achievement and maintenance of target temperature and control of shivering [74]. A short-acting NMB can be helpful in patients with refractory shivering who are sedated with continuous propofol/midazolam use. Some older studies suggest that continuous NMB has a beneficial effect and improves outcome [75-77]. Currently, intermittent dosing is preferred to continuous infusions. Continuous NMB infusion was not associated with improved outcomes in one small randomized controlled trial [78]. A multicenter study found that intermittent as needed NMB was associated with improved outcomes when compared to continuous NMB [79]. NMB should be used only if the patients are completely sedated. Moreover, clinicians have to be careful of the risk of pressure injury, deep vein thrombosis, and critical illness polyneuropathy resulting from complete immobilization. NMB masks seizures that are typically detected during the neurological evaluation. EEG monitoring should be considered in comatose patients after cardiac arrest, particularly if NMB is used $[12,80]$.

\section{TTM MAINTENANCE AND DURATION}

There are many guidelines and reviews for detailed discussion of 
the entire course of TTM (Fig. 4) [29,81]. Patients are maintained at the target temperature for at least 24 hours (maintenance phase); different studies have reported a range of durations, from 12 to 48 hours, but 24 hours is generally recommended (Table 1) [29]. Regarding the optimal duration of TTM, Kirkegaard et al. [7] reported that there was no significant difference in 6-month survival between therapeutic hypothermia at $33^{\circ} \mathrm{C}$ for 24 and 48 hours among patients with combined cardiac rhythm (shockable, 90\%). During the maintenance phase, the variation of temperature should be managed to be minimal, because trials have shown that huge variations of temperature (overcooling) might be linked to complications, like infection $[8,82,83]$. Several studies suggest the association between minimal variation in temperature and a high percentage of favorite neurologic outcomes; they are summarized in Table 1 [7].

\section{SEIZURE MANAGEMENT AND CONTINUOUS EEG}

\section{Detection of seizures}

Seizures are caused by abnormal excessive or synchronous neuronal activity in the brain [84]. Seizures are not only the result of brain injury caused by cardiac arrest but also a risk for secondary brain injury. They are classified as generalized convulsive seizures or nonconvulsive seizures; muscle contraction and relaxation are absent in the case of nonconvulsive seizures.

The incidence of nonconvulsive status epilepticus (NCSE) in comatose postarrest patients is $12 \%$ to $24 \%$ in adult PCAS [ 85 88 ]; an even higher incidence (47\%) has been reported in pediatric cardiac arrest [86]. Other abnormal EEG patterns are found in maximally $40 \%$ of patients which are treatable [87]. Based on continuous EEG (cEEG) records, some studies indicate that seizures occur most often within the first 8 hours after ROSC $[85,87,88]$. Seizures are masked by NMB in $3 \%$ to $44 \%$ of cases $[85,86,89,90]$. For these reasons, cEEG monitoring and assessment of NCSE during the induction, maintenance, and rewarming periods are indicated for all TTM patients (Figs. 4, 5) $[86,91,92]$. Seizures following cardiac arrest are associated with increased mortality $[85,87,88]$.

\section{Prophylactic and therapeutic use of antiepileptic drugs Some investigations have revealed that antiepileptic drugs (AEDs) do not decrease the incidence of convulsive seizures or improve neurologic outcome $[93,94]$; furthermore, the effects of AEDs are not standardized. As there is no standard method to diagnose seizures using cEEG and drugs may cause adverse effects (hypo- tension, etc.), the prophylactic use of AEDs is not recommended.}

\begin{tabular}{|c|c|}
\hline Neurology & $\begin{array}{l}\text { cEEG: continuous pattern or not } \\
\text { Pupil size, light reflex, and NPi } \\
\text { Shivering control (Fig. 3) } \\
\text { Seizure control }\end{array}$ \\
\hline Circulation & $\begin{array}{l}\text { Goal MAP > } 80 \mathrm{~mm} \mathrm{Hg} \text { for cerebral perfusion pressure } \\
\text { Differential diagnosis: } \\
\text { hypovolemic shock: cold diuresis (most), bleeding due to CPR } \\
\text { cardiogenic shock: stunning } \\
\text { distributive shock: sepsis, anaphylaxis } \\
\text { obstructive shock: tension pneumothorax, cardiac tamponade } \\
\text { Bradycardia: usually no treatment, if not with hypotension }\end{array}$ \\
\hline Respiration & $\begin{array}{l}\text { Goal } \mathrm{PaO}_{2} 70-100 \mathrm{~mm} \mathrm{Hg} \\
\text { Goal } \mathrm{PaCO}_{2} 40 \pm 5 \mathrm{~mm} \mathrm{Hg}\end{array}$ \\
\hline Renal, Electrolytes & $\begin{array}{l}\text { Cold diuresis } \\
\text { Decrease: } \mathrm{K}, \mathrm{Mg} \text {, phosphorus } \\
\text { Intracellular shift during cooling: warning for re-increase with rewarming } \\
\text { Goal } \mathrm{K}>4.0 \mathrm{mEq} / \mathrm{L} \\
\text { Goal } \mathrm{Mg}>2 \mathrm{mg} / \mathrm{dL} \\
\text { Goal phosphorus }>3 \mathrm{mg} / \mathrm{dL}\end{array}$ \\
\hline Blood sugar & $\begin{array}{l}\text { Goal blood sugar unknown (>90 mg/dL), avoid hypoglycemia/hyperglycemia } \\
\text { Increased insulin resistance, insulin drip }\end{array}$ \\
\hline Anemia & $\begin{array}{l}\text { Disturbed coagulation } \leq 35^{\circ} \mathrm{C} \\
\text { Caution for mild bleeding, especially with ECPR }\end{array}$ \\
\hline Drug & Decreased pharmacokinetics/drug metabolism \\
\hline
\end{tabular}

Fig. 4. Systemic considerations during the maintenance phase of targeted temperature management (TTM). cEEG, continuous electroencephalography; NPi, neurological pupil index; MAP, mean arterial pressure; CPR, cardiopulmonary resuscitation; ECPR, extracorporeal cardiopulmonary resuscitation. 


\begin{tabular}{|l|l|}
\hline Neurology & $\begin{array}{l}\text { cEEG: continuous pattern or not } \\
\text { Pupil size, light reflex, and NPi } \\
\text { Shivering control (Fig. 3) } \\
\text { After rewarming, stop neuromuscular blockade, then stop analgesics/sedatives } \\
\text { Seizure control }\end{array}$ \\
\hline Rewarming strategy & $\begin{array}{l}\text { Target temperature: } 36.0^{\circ} \mathrm{C} \\
\text { Speed: } 0.1^{\circ} \mathrm{C} / \mathrm{hr} \\
\text { Duration: generally need } 36 \text { hours (from } 33.0^{\circ} \mathrm{C} \text { ) }\end{array}$ \\
\hline Normothermia after rewarming & $\begin{array}{l}\text { Until } 72 \mathrm{hr} \text { after ROSC: }>36.0^{\circ} \mathrm{C} \\
\text { After } 72 \mathrm{hr} \text { after ROSC: }>38.0^{\circ} \mathrm{C}\end{array}$ \\
\hline Circulation & Avoid hypotension \\
\hline Electrolyte & Avoid hyperkalemia \\
\hline Blood sugar & Avoid hypoglycemia \\
\hline
\end{tabular}

Fig. 5. Special considerations during the rewarming phase of targeted temperature management. cEEG, continuous electroencephalography; $\mathrm{NPi}$, neurological pupil index; ROSC, return of spontaneous circulation.

There is no high-grade evidence showing a relationship between AED use and survival or neurologic outcome [95-97], but as seizures may lead to secondary brain injury, treatment of recurrent seizures could be considered as standard therapy in comatose patients with PCAS.

\section{CIRCULATORY CARE}

\section{Optimal mean arterial blood pressure and cerebral perfusion pressure}

Transient myocardial systolic or diastolic dysfunction [98-101] and a decline in systemic vascular resistance [100] has been observed in PCAS, but may be less clinically significant and can be managed conservatively [101]. One study showed the best survival in patients with a mean arterial blood pressure (MAP) of 76 to $86 \mathrm{~mm} \mathrm{Hg}$ and mixed venous oxygen saturation of $67 \%$ to $72 \%$ [102]. Another study reported that a time-weighted average MAP $\geq 70 \mathrm{~mm} \mathrm{Hg}$ was associated with a better neurologic outcome than lower levels [103]. MAP $\geq 100 \mathrm{~mm} \mathrm{Hg}$ during the 2 hours after ROSC was associated with better neurologic recovery at hospital discharge (retrospectively examined) [104]. Young et al. [105], however, found no relationship between higher MAP during therapeutic hypothermia and neurologically intact survival. Bundled care with goals of MAP of 80 to $100 \mathrm{~mm} \mathrm{Hg}$, central venous pressure $(\mathrm{CVP}) \geq 8 \mathrm{~mm} \mathrm{Hg}$, and central venous oxygen saturation $\geq 65 \%$ led to better neurologic outcomes and less mortality than in historic controls [106]. A bundle requiring MAP $\geq 65$ to $70 \mathrm{~mm} \mathrm{Hg}, \mathrm{CVP} \geq 8$ to $12 \mathrm{~mm} \mathrm{Hg}$, and hemoglobin $\geq 9$ to $10 \mathrm{~g} / \mathrm{dL}$ showed a better survival rate to hospital discharge and neurologic outcome at 1 year [89].

Regarding cerebral perfusion pressure (CPP) in PCAS patients in a previous study [107], ICP increased to around median 10 $\mathrm{mm} \mathrm{Hg}$ (interquartile range [IQR], 5 to 20 ) in patients with good outcomes and to $25 \mathrm{~mm} \mathrm{Hg}$ (IQR, 10 to 30) in those with poor outcomes. A relatively low burden of intracranial hypertension (ICP > $20 \mathrm{~mm} \mathrm{Hg}$ ) was also reported [108,109]. After ROSC, prolonged cerebral hypoperfusion develops within hours and may last for hours to days [110]. During this hypoperfusion, cerebral vascular resistance is increased, and pressure autoregulation is right-shifted or absent, resulting in decreased blood flow oxygen delivery and increased CPP needed to maintain microvascular flow [111,112]. Observational studies show a consistent association between lower postarrest blood pressure and mortality $[113,114]$. Moreover, maintaining a MAP $>80 \mathrm{~mm} \mathrm{Hg}$ is associated with improved outcomes, even if achieved using a vasopressor $[89,106,113,115]$. Recently, Sekhon et al. [116] reported that the optimal MAP to prevent brain hypoxia in case series with multimodal neuromonitoring is about $80 \mathrm{~mm} \mathrm{Hg}$.

Studies suggest that the MAP should be kept higher than a defined threshold during the postarrest period considering CPP in the damaged brain. Although there is some concern about higher MAP achieved using vasoactive agents and poor outcomes [27], recently, Jakkula et al. [117] reported, based on a multicenter study, that there is no significant difference in neuron-specific enolase concentration at 48 hours after cardiac arrest and neurologic outcome between low-normal (65 to $75 \mathrm{mmHg}$ ) and high-normal ( 80 to $100 \mathrm{~mm} \mathrm{Hg}$ ) MAP management [117]. There is no evidence that a higher MAP causes increased ICP and worsening of outcome. Taken together, it is important to maintain CPP normally, and considering CPP, it is suggested that MAP should be maintained over $80 \mathrm{~mm} \mathrm{Hg}$ (Fig. 4). 


\section{Fluid resuscitation}

The amount of fluid required to maintain MAP after arrest was reported to be 3.5 to $6 \mathrm{~L}[99,100]$. However, the relationship between fluid or blood products and outcome after ROSC is unclear, in contrast to what is known about albumin in sepsis [118]. If fluid resuscitation alone is ineffective, it is reasonable to use vasoactive drugs $[100,113]$. In patients with acute coronary syndrome, emergency CAG with/without PCI should be considered [119].

\section{Heart rate and arrhythmia management}

In hypothermia, bradycardia occurs normally and is associated with reduced systolic dysfunction in animal models [120]. A heart rate of 30 to 40 beats $/ \mathrm{min}$ is common at TTM $33^{\circ} \mathrm{C}$ and generally does not require therapy unless associated with hypotension [1]. Bradycardia may be more pronounced at lower target temperatures; symptomatic bradycardia may be treated using a beta agonist instead of atropine, which has been found to be ineffective [1].

A lowered heart rate during TTM is considered to be associated with favorable outcomes. A recent study has shown that bradycardia and a low heart rate are predictors of favorable neurological outcomes $[121,122]$. More recently, a relationship between the heart rate response during rewarming and favorable outcomes has been suggested [123]. In this study, an increased heart rate during rewarming predicted favorable neurological outcomes. The heart rate during TTM is a key indicator of brain variability.

Arrhythmias may develop if the core temperature accidentally falls below $28^{\circ} \mathrm{C}\left(30^{\circ} \mathrm{C}\right.$ if electrolyte disorders are present); therefore, the core temperature must be maintained above $30^{\circ} \mathrm{C}$. Arrhythmias should not be viewed as a reason to discontinue TTM. QT prolongation is common during TTM, and concomitant QT prolonging drugs should be used with caution [1].

\section{RESPIRATORY CARE}

\section{Oxygenation}

The cause of hypoxemia in patients with PCAS includes lung contusion induced by chest compressions, atelectasis, ventilator-associated lung injury, and others. It is no wonder that hypoxemia in PCAS may induce secondary brain damage beyond that during the arrest itself because of inadequate cerebral oxygen delivery. Some studies have indicated that hypoxemia after ROSC is associated with worse outcomes than normoxemia [124-126]; therefore, hypoxemia may need to be avoided after ROSC.

Positive end-expiratory pressure (PEEP) is another factor associated with oxygenation. Protective mechanical ventilation with a lower tidal volume and higher PEEP is more commonly used after cardiac arrest. This appears to reduce the incidence of pulmonary complications, although other organs are still at risk [127]. A consensus on PEEP settings for patients with PCAS is lacking, although increasing PEEP may elevate ICP [128]. It may be rational to maintain the PEEP as low as possible as long as higher concentrations of oxygen can be avoided.

Hyperoxemia after ROSC promotes the formation of reactive oxygen species (oxidative stress), which can induce secondary injury in brain tissue already damaged by cardiac arrest. Both observational studies $[124,126,129,130]$ and metaanalyses [131-133] show that hyperoxemia is associated with poor survival and neurologic outcome in PCAS. Although the conclusions of other studies have differed $[125,134]$, it may be necessary to avoid hyperoxemia after ROSC.

It may be concluded that both hypoxia and hyperoxia should be avoided, and a $\mathrm{PaO}_{2}$ of 70 to $100 \mathrm{~mm} \mathrm{Hg}$ is reasonable (Fig. 4).

\section{Ventilation}

Although cerebral pressure autoregulation may be impaired after resuscitation, $\mathrm{CO}_{2}$ reactivity of the cerebral vasculature after ROSC is preserved during mild therapeutic hypothermia $[135,136]$, and therefore, $\mathrm{CO}_{2}$ should be controlled during TTM. Hypocapnia following hyperventilation causes cerebral vasoconstriction and inadequate blood flow, based on some observational studies, and it can certainly cause and/or worsen cerebral ischemia, worsen outcome, and cause injury to other organs in PCAS [137-140].

Increased $\mathrm{PaCO}_{2}$ may cause further worsening of an elevated ICP by increasing the CBF. However, evidence of the effect of hypercapnia on outcome after ROSC is conflicting [134,138-140]. Although a phase II randomized controlled trial found that S100 calcium-binding protein beta concentrations decreased over time in patients with $\mathrm{PaCO}_{2}$ maintained at 50 to $55 \mathrm{~mm} \mathrm{Hg}$ but not in those with a $\mathrm{PaCO}_{2}$ of 35 to $45 \mathrm{~mm} \mathrm{Hg}$ and better functional recovery with a $\mathrm{PaCO}_{2}$ of 50 to $55 \mathrm{~mm} \mathrm{Hg}$, hospital mortality did not differ significantly between the two groups [141].

Taken together, the risk of poor outcome appears to differ for hypocapnia and hypercapnia, even if $\mathrm{PaCO}_{2}$ deviations from normal are comparable (Fig. 4). Although there is insufficient evidence to recommend routine use of mild hypercapnia after cardiac arrest, hyperventilation should be avoided.

\section{ELECTROLYTE MANAGEMENT AND GLYCEMIC CONTROL}

During hypothermia induction, particularly to lower target tem- 
peratures, an initial cold diuresis may result in hypokalemia, hypomagnesaemia, and hypophosphatemia. Moreover, hypothermia moves potassium from the extracellular to intracellular space. Frequent assessment of electrolytes and repletion is indicated. Repletion of potassium is carefully done, since serum potassium levels will predictably rise when rewarming is initiated. A target potassium level of $4.0 \mathrm{mmol} / \mathrm{L}$ is reasonable during TTM induction and maintenance [29]. Magnesium and phosphorus should be maintained in the high to normal range (Fig. 4).

Glycemic control is important in the management of critically ill patients. The current concepts of glycemic control recommend avoiding hypoglycemia and minimizing glycemic variability (GV). One database study in France showed that smaller magnitudes of GV were observed in patients with a good neurologic outcome compared with those with a poor outcome [142]. Other studies reported that increased GV was associated with increased mortality and unfavorable neurologic outcome $[143,144]$. This suggests that attention should be paid to GV. In patients with PCAS, the optimal target range remains unknown. However, insulin sensitivity increases and blood glucose levels decrease as body temperature rises during TTM. Further, patients with diabetes may be tolerant to higher glucose values. Blood glucose levels should be checked frequently to avoid hypoglycemia and hyperglycemia (Fig. 4).

\section{REWARMING AFTER TTM}

The rewarming phase follows maintenance and should be slow and controlled in order to avoid critical complications. Active normothermia is typically maintained for 24 to 48 hours after rewarming is completed (Fig. 5). Recently, Hifumi et al. [145] reported that a longer rewarming duration was significantly associated with and was as an independent predictor of favorable neurologic outcomes in OHCA patients who received therapeutic hypothermia.

\section{PROGNOSTICATION}

Even clinical findings like brain death are not definitive for at least 24 hours following ROSC [146]. In the first 72 hours after cardiac arrest, no sign, symptom, or combination of findings short of brain death precludes favorable recovery $[12,147]$. As in many neurocritical care conditions, however, accurate neurological prognostication after ROSC is challenging. Pupil diameter and/ or pupil light reflex might be associated with brain injury. Recently quantitative pupillometry has allowed a more comprehensive assessment of pupillary function when using pupillary light reflex
(PLR) and/or neurological pupil index (NPi). The PLR is expressed as the percentage pupillary constriction in response to a calibrated light stimulus, and PLR $<10 \%$ is considered as abnormal. The NPi is a scalar value (between 0 and $5,<3$ is considered as abnormal) which is calculated based on an algorithm that accounts for several measured pupillary variables, including size, percentage constriction, constriction velocity, dilation velocity, and latency. Oddo et al. [148] reported, based on a multicenter study, that $\mathrm{NPi}<2.0$ at day 1 to 3 after cardiac arrest has an association with poor neurologic outcome (specificity 1.0). Based on earlier estimation of neurologic outcome, Riker et al. [149] reported that 6 hours after ROSC, an NPi $<1.5$ was associated with poor neurologic outcome (specificity 1.0). In both studies, sensitivity was low. In Japan, Tamura et al. [150] reported that 0 hour after ROSC, the cutoff value of PLR $11 \%$ was associated with favorable neurologic outcome (specificity 0.81 ). Regarding cEEG, Ruijter et al. [151] recently reported that continuous background patterns at 12 hours after cardiac arrest are associated with good recovery (specificity 0.91$)$ and suppression $(<10 \mu \mathrm{V})$ pattern with poor outcome (specificity 1.0) [151]. Using EEG, poor outcome may be predicted within 24 hours after cardiac arrest under TTM.

Withdrawal of life-sustaining therapy based on perceived neurological prognosis has been linked to preventable deaths after cardiac arrest $[152,153]$. Early aggressive care must be performed initially.

\section{CONCLUSION}

TTM for PCAS is a fundamental strategy in neurocritical care. Further studies are needed to identify the types of cases in which patients would benefit from TTM and to determine the optimal target temperature and duration of TTM.

\section{ARTICLE INFORMATION}

\section{Conflict of interest}

No potential conflict of interest relevant to this article.

\section{ORCID}

Yasuhiro Kuroda, https://orcid.org/0000-0002-7562-3187

Kenya Kawakita, https://orcid.org/0000-0001-7898-8360

\section{Author contributions}

Conceptualization \& Writing-original draft: YK. Writing-review editing: KK. 


\section{REFERENCES}

1. Polderman KH. Mechanisms of action, physiological effects, and complications of hypothermia. Crit Care Med 2009;37(7 Suppl):S186-202.

2. Sekhon MS, Ainslie PN, Griesdale DE. Clinical pathophysiology of hypoxic ischemic brain injury after cardiac arrest: a "twohit" model. Crit Care 2017;21:90.

3. Bro-Jeppesen J, Hassager C, Wanscher M, Søholm H, Thomsen $\mathrm{JH}$, Lippert FK, et al. Post-hypothermia fever is associated with increased mortality after out-of-hospital cardiac arrest. Resuscitation 2013;84:1734-40.

4. Zeiner A, Holzer M, Sterz F, Schörkhuber W, Eisenburger P, Havel C, et al. Hyperthermia after cardiac arrest is associated with an unfavorable neurologic outcome. Arch Intern Med 2001;161:2007-12.

5. Hypothermia after Cardiac Arrest Study Group. Mild therapeutic hypothermia to improve the neurologic outcome after cardiac arrest. N Engl J Med 2002;346:549-56.

6. Bernard SA, Gray TW, Buist MD, Jones BM, Silvester W, Gutteridge $\mathrm{G}$, et al. Treatment of comatose survivors of out-of-hospital cardiac arrest with induced hypothermia. N Engl J Med 2002;346:557-63.

7. Kirkegaard H, Søreide E, de Haas I, Pettilä V, Taccone FS, Arus $\mathrm{U}$, et al. Targeted temperature management for 48 vs 24 hours and neurologic outcome after out-of-hospital cardiac arrest: a randomized clinical trial. JAMA 2017;318:341-50.

8. Nielsen N, Wetterslev J, Cronberg T, Erlinge D, Gasche Y, Hassager $\mathrm{C}$, et al. Targeted temperature management at $33^{\circ} \mathrm{C}$ versus $36^{\circ} \mathrm{C}$ after cardiac arrest. N Engl J Med 2013;369:2197-206.

9. Lopez-de-Sa E, Rey JR, Armada E, Salinas P, Viana-Tejedor A, Espinosa-Garcia S, et al. Hypothermia in comatose survivors from out-of-hospital cardiac arrest: pilot trial comparing 2 levels of target temperature. Circulation 2012;126:2826-33.

10. Yokoyama H, Nagao K, Hase M, Tahara Y, Hazui H, Arimoto H, et al. Impact of therapeutic hypothermia in the treatment of patients with out-of-hospital cardiac arrest from the J-PULSE-HYPO study registry. Circ J 2011;75:1063-70.

11. Donnino MW, Andersen LW, Berg KM, Reynolds JC, Nolan JP, Morley PT, et al. Temperature management after cardiac arrest: an advisory statement by the advanced life support task force of the International Liaison Committee on Resuscitation and the American Heart Association Emergency Cardiovascular Care Committee and the Council on Cardiopulmonary, Critical Care, Perioperative and Resuscitation. Resuscitation 2016; 98:97-104.

12. Callaway CW, Donnino MW, Fink EL, Geocadin RG, Golan E,
Kern KB, et al. Part 8: post-cardiac arrest care. 2015 American Heart Association guidelines update for cardiopulmonary resuscitation and emergency cardiovascular care. Circulation 2015;132(18 Suppl 2):S465-82.

13. Geocadin RG, Wijdicks E, Armstrong MJ, Damian M, Mayer SA, Ornato JP, et al. Practice guideline summary: reducing brain injury following cardiopulmonary resuscitation. Report of the Guideline Development, Dissemination, and Implementation Subcommittee of the American Academy of Neurology. Neurology 2017;88:2141-9.

14. Deye N, Vincent F, Michel P, Ehrmann S, da Silva D, Piagnerelli $\mathrm{M}$, et al. Changes in cardiac arrest patients' temperature management after the 2013 "TTM" trial: results from an international survey. Ann Intensive Care 2016;6:4.

15. Bradley SM, Liu W, McNally B, Vellano K, Henry TD, Mooney MR, et al. Temporal trends in the use of therapeutic hypothermia for out-of-hospital cardiac arrest. JAMA Netw Open 2018;1:e184511.

16. Lundbye JB, Rai M, Ramu B, Hosseini-Khalili A, Li D, Slim HB, et al. Therapeutic hypothermia is associated with improved neurologic outcome and survival in cardiac arrest survivors of non-shockable rhythms. Resuscitation 2012;83:202-7.

17. Testori C, Sterz F, Behringer W, Haugk M, Uray T, Zeiner A, et al. Mild therapeutic hypothermia is associated with favourable outcome in patients after cardiac arrest with non-shockable rhythms. Resuscitation 2011;82:1162-7.

18. Arrich J, European Resuscitation Council Hypothermia After Cardiac Arrest Registry Study Group. Clinical application of mild therapeutic hypothermia after cardiac arrest. Crit Care Med 2007;35:1041-7.

19. Dumas F, Grimaldi D, Zuber B, Fichet J, Charpentier J, Pène F, et al. Is hypothermia after cardiac arrest effective in both shockable and nonshockable patients?: insights from a large registry. Circulation 2011;123:877-86.

20. Don CW, Longstreth WT Jr, Maynard C, Olsufka M, Nichol G, Ray $\mathrm{T}$, et al. Active surface cooling protocol to induce mild therapeutic hypothermia after out-of-hospital cardiac arrest: a retrospective before-and-after comparison in a single hospital. Crit Care Med 2009;37:3062-9.

21. Soga T, Nagao K, Sawano H, Yokoyama H, Tahara Y, Hase M, et al. Neurological benefit of therapeutic hypothermia following return of spontaneous circulation for out-of-hospital non-shockable cardiac arrest. Circ J 2012;76:2579-85.

22. Lascarrou JB, Merdji H, Le Gouge A, Colin G, Grillet G, Girardie $\mathrm{P}$, et al. Targeted temperature management for cardiac arrest with nonshockable rhythm. N Engl J Med 2019;381:2327-37.

23. Nolan JP, Neumar RW, Adrie C, Aibiki M, Berg RA, Böttiger 
BW, et al. Post-cardiac arrest syndrome: epidemiology, pathophysiology, treatment, and prognostication. A Scientific Statement from the International Liaison Committee on Resuscitation; the American Heart Association Emergency Cardiovascular Care Committee; the Council on Cardiovascular Surgery and Anesthesia; the Council on Cardiopulmonary, Perioperative, and Critical Care; the Council on Clinical Cardiology; the Council on Stroke. Resuscitation 2008;79:350-79.

24. Chan PS, Berg RA, Tang Y, Curtis LH, Spertus JA, American Heart Association's Get With the Guidelines-Resuscitation Investigators. Association between therapeutic hypothermia and survival after in-hospital cardiac arrest. JAMA 2016;316:137582.

25. Natsukawa T, Sawano H, Natsukawa M, Yoshinaga Y, Sato S, Ito $\mathrm{Y}$, et al. At what level of unconsciousness is mild therapeutic hypothermia indicated for out-of-hospital cardiac arrest: a retrospective, historical cohort study. J Intensive Care 2015;3:38.

26. Polderman KH. Induced hypothermia and fever control for prevention and treatment of neurological injuries. Lancet 2008; 371:1955-69.

27. Bro-Jeppesen J, Annborn M, Hassager C, Wise MP, Pelosi P, Nielsen N, et al. Hemodynamics and vasopressor support during targeted temperature management at $33^{\circ} \mathrm{C}$ versus $36^{\circ} \mathrm{C}$ after out-of-hospital cardiac arrest: a post hoc study of the target temperature management trial. Crit Care Med 2015;43:318-27.

28. Stanger D, Kawano T, Malhi N, Grunau B, Tallon J, Wong GC, et al. Door-to-targeted temperature management initiation time and outcomes in out-of-hospital cardiac arrest: insights from the continuous chest compressions trial. J Am Heart Assoc 2019;8:e012001.

29. Madden LK, Hill M, May TL, Human T, Guanci MM, Jacobi J, et al. The implementation of targeted temperature management: an evidence-based guideline from the Neurocritical Care Society. Neurocrit Care 2017;27:468-87.

30. Polderman KH, Herold I. Therapeutic hypothermia and controlled normothermia in the intensive care unit: practical considerations, side effects, and cooling methods. Crit Care Med 2009;37:1101-20.

31. Kim F, Olsufka M, Longstreth WT Jr, Maynard C, Carlbom D, Deem S, et al. Pilot randomized clinical trial of prehospital induction of mild hypothermia in out-of-hospital cardiac arrest patients with a rapid infusion of 4 degrees $\mathrm{C}$ normal saline. Circulation 2007;115:3064-70.

32. Kim F, Nichol G, Maynard C, Hallstrom A, Kudenchuk PJ, Rea $\mathrm{T}$, et al. Effect of prehospital induction of mild hypothermia on survival and neurological status among adults with cardiac arrest: a randomized clinical trial.JAMA 2014;311:45-52.
33. Ortega-Deballon I, Hornby L, Shemie SD, Bhanji F, Guadagno E. Extracorporeal resuscitation for refractory out-of-hospital cardiac arrest in adults: a systematic review of international practices and outcomes. Resuscitation 2016;101:12-20.

34. Sakamoto T, Morimura N, Nagao K, Asai Y, Yokota H, Nara S, et al. Extracorporeal cardiopulmonary resuscitation versus conventional cardiopulmonary resuscitation in adults with out-of-hospital cardiac arrest: a prospective observational study. Resuscitation 2014;85:762-8.

35. Hovdenes J, Laake JH, Aaberge L, Haugaa H, Bugge JF. Therapeutic hypothermia after out-of-hospital cardiac arrest: experiences with patients treated with percutaneous coronary intervention and cardiogenic shock. Acta Anaesthesiol Scand 2007;51:137-42.

36. Nagao K, Kikushima K, Watanabe K, Tachibana E, Tominaga Y, Tada K, et al. Early induction of hypothermia during cardiac arrest improves neurological outcomes in patients with out-of-hospital cardiac arrest who undergo emergency cardiopulmonary bypass and percutaneous coronary intervention. Circ J 2010;74:77-85.

37. Garcia-Tejada J, Jurado-Román A, Rodríguez J, Velázquez M, Hernández F, Albarrán A, et al. Post-resuscitation electrocardiograms, acute coronary findings and in-hospital prognosis of survivors of out-of-hospital cardiac arrest. Resuscitation 2014; 85:1245-50.

38. Salam I, Hassager C, Thomsen JH, Langkjær S, Søholm H, Bro-Jeppesen J, et al. Editor's choice. Is the pre-hospital ECG after out-of-hospital cardiac arrest accurate for the diagnosis of ST-elevation myocardial infarction? Eur Heart J Acute Cardiovasc Care 2016;5:317-26.

39. Dumas F, Cariou A, Manzo-Silberman S, Grimaldi D, Vivien B, Rosencher J, et al. Immediate percutaneous coronary intervention is associated with better survival after out-of-hospital cardiac arrest: insights from the PROCAT (Parisian Region Out of hospital Cardiac ArresT) registry. Circ Cardiovasc Interv 2010;3:200-7.

40. Lemkes JS, Janssens GN, van der Hoeven NW, Jewbali LSD, Dubois EA, Meuwissen M, et al. Coronary angiography after cardiac arrest without ST-segment elevation. N Engl J Med 2019;380:1397-407.

41. Abella BS, Gaieski DF. Coronary angiography after cardiac arrest: the right timing or the right patients? $\mathrm{N}$ Engl J Med 2019;380:1474-5.

42. Kern KB, Lotun K, Patel N, Mooney MR, Hollenbeck RD, McPherson JA, et al. Outcomes of comatose cardiac arrest survivors with and without ST-segment elevation myocardial infarction: importance of coronary angiography. JACC Cardio- 
vasc Interv 2015;8:1031-40.

43. Zanuttini D, Armellini I, Nucifora G, Carchietti E, Trillò G, Spedicato L, et al. Impact of emergency coronary angiography on in-hospital outcome of unconscious survivors after out -of-hospital cardiac arrest. Am J Cardiol 2012;110:1723-8.

44. Callaway CW, Schmicker RH, Brown SP, Albrich JM, Andrusiek DL, Aufderheide TP, et al. Early coronary angiography and induced hypothermia are associated with survival and functional recovery after out-of-hospital cardiac arrest. Resuscitation 2014;85:657-63.

45. Gräsner JT, Meybohm P, Caliebe A, Böttiger BW, Wnent J, Messelken $\mathrm{M}$, et al. Postresuscitation care with mild therapeutic hypothermia and coronary intervention after out-of-hospital cardiopulmonary resuscitation: a prospective registry analysis. Crit Care 2011;15:R61.

46. Götberg M, Olivecrona GK, Koul S, Carlsson M, Engblom H, Ugander M, et al. A pilot study of rapid cooling by cold saline and endovascular cooling before reperfusion in patients with ST-elevation myocardial infarction. Circ Cardiovasc Interv 2010;3:400-7.

47. Erlinge D, Götberg M, Lang I, Holzer M, Noc M, Clemmensen $\mathrm{P}$, et al. Rapid endovascular catheter core cooling combined with cold saline as an adjunct to percutaneous coronary intervention for the treatment of acute myocardial infarction. The CHILL-MI trial: a randomized controlled study of the use of central venous catheter core cooling combined with cold saline as an adjunct to percutaneous coronary intervention for the treatment of acute myocardial infarction. J Am Coll Cardiol 2014;63:1857-65.

48. Noc M, Erlinge D, Neskovic AN, Kafedzic S, Merkely B, Zima E, et al. COOLAMI EU pilot trial: a multicentre, prospective, randomised controlled trial to assess cooling as an adjunctive therapy to percutaneous intervention in patients with acute myocardial infarction. EuroIntervention 2017;13:e531-9.

49. Bro-Jeppesen J, Kjaergaard J, Wanscher M, Pedersen F, Holmvang L, Lippert FK, et al. Emergency coronary angiography in comatose cardiac arrest patients: do real-life experiences support the guidelines? Eur Heart J Acute Cardiovasc Care 2012;1:291301.

50. Hollenbeck RD, McPherson JA, Mooney MR, Unger BT, Patel NC, McMullan PW Jr, et al. Early cardiac catheterization is associated with improved survival in comatose survivors of cardiac arrest without STEMI. Resuscitation 2014;85:88-95.

51. Brophy GM, Human T, Shutter L. Emergency neurological life support: pharmacotherapy. Neurocrit Care 2015;23 Suppl 2:S48-68.

52. Bray JE, Stub D, Bloom JE, Segan L, Mitra B, Smith K, et al.
Changing target temperature from $33^{\circ} \mathrm{C}$ to $36^{\circ} \mathrm{C}$ in the ICU management of out-of-hospital cardiac arrest: a before and after study. Resuscitation 2017;113:39-43.

53. Badjatia N, Strongilis E, Gordon E, Prescutti M, Fernandez L, Fernandez A, et al. Metabolic impact of shivering during therapeutic temperature modulation: the Bedside Shivering Assessment Scale. Stroke 2008;39:3242-7.

54. Choi HA, Ko SB, Presciutti M, Fernandez L, Carpenter AM, Lesch C, et al. Prevention of shivering during therapeutic temperature modulation: the Columbia anti-shivering protocol. Neurocrit Care 2011;14:389-94.

55. Rittenberger JC, Polderman KH, Smith WS, Weingart SD. Emergency neurological life support: resuscitation following cardiac arrest. Neurocrit Care 2012;17 Suppl 1:S21-8.

56. van Zanten AR, Polderman KH. Blowing hot and cold? Skin counter warming to prevent shivering during therapeutic cooling. Crit Care Med 2009;37:2106-8.

57. Badjatia N, Strongilis E, Prescutti M, Fernandez L, Fernandez A, Buitrago M, et al. Metabolic benefits of surface counter warming during therapeutic temperature modulation. Crit Care Med 2009;37:1893-7.

58. Nair SU, Lundbye JB. The occurrence of shivering in cardiac arrest survivors undergoing therapeutic hypothermia is associated with a good neurologic outcome. Resuscitation 2013;84:626-9.

59. Perman SM, Ellenberg JH, Grossestreuer AV, Gaieski DF, Leary M, Abella BS, et al. Shorter time to target temperature is associated with poor neurologic outcome in post-arrest patients treated with targeted temperature management. Resuscitation 2015;88:114-9.

60. Leão RN, Ávila P, Cavaco R, Germano N, Bento L. Therapeutic hypothermia after cardiac arrest: outcome predictors. Rev Bras Ter Intensiva 2015;27:322-32.

61. Riker RR, Gagnon DJ, May T, Seder DB, Fraser GL. Analgesia, sedation, and neuromuscular blockade during targeted temperature management after cardiac arrest. Best Pract Res Clin Anaesthesiol 2015;29:435-50.

62. Keegan MT. Sedation in the neurologic intensive care unit. Curr Treat Options Neurol 2008;10:111-25.

63. Samaniego EA, Mlynash M, Caulfield AF, Eyngorn I, Wijman CA. Sedation confounds outcome prediction in cardiac arrest survivors treated with hypothermia. Neurocrit Care 2011; 15:113-9.

64. Ponz I, Lopez-de-Sa E, Armada E, Caro J, Blazquez Z, Rosillo S, et al. Influence of the temperature on the moment of awakening in patients treated with therapeutic hypothermia after cardiac arrest. Resuscitation 2016;103:32-6.

65. Rey A, Rossetti AO, Miroz JP, Eckert P, Oddo M. Late awaken- 
ing in survivors of postanoxic coma: early neurophysiologic predictors and association with ICU and long-term neurologic recovery. Crit Care Med 2019;47:85-92.

66. Helbok R, Kurtz P, Schmidt MJ, Stuart MR, Fernandez L, Connolly $S E$, et al. Effects of the neurological wake-up test on clinical examination, intracranial pressure, brain metabolism and brain tissue oxygenation in severely brain-injured patients. Crit Care 2012;16:R226.

67. Dell'Anna AM, Taccone FS, Halenarova K, Citerio G. Sedation after cardiac arrest and during therapeutic hypothermia. Minerva Anestesiol 2014;80:954-62.

68. Marik PE. Propofol: therapeutic indications and side-effects. Curr Pharm Des 2004;10:3639-49.

69. Patel P. An update on neuroanesthesia for the occasional neuroanesthesiologist. Can J Anesth 2005;52:R36-41.

70. Roberts DJ, Hall RI, Kramer AH, Robertson HL, Gallagher CN, Zygun DA. Sedation for critically ill adults with severe traumatic brain injury: a systematic review of randomized controlled trials. Crit Care Med 2011;39:2743-51.

71. Tortorici MA, Kochanek PM, Poloyac SM. Effects of hypothermia on drug disposition, metabolism, and response: a focus of hypothermia-mediated alterations on the cytochrome P450 enzyme system. Crit Care Med 2007;35:2196-204.

72. Degos V, Charpentier TL, Chhor V, Brissaud O, Lebon S, Schwendimann L, et al. Neuroprotective effects of dexmedetomidine against glutamate agonist-induced neuronal cell death are related to increased astrocyte brain-derived neurotrophic factor expression. Anesthesiology 2013;118:1123-32.

73. Callaway CW, Elmer J, Guyette FX, Molyneaux BJ, Anderson $\mathrm{KB}$, Empey PE, et al. Dexmedetomidine reduces shivering during mild hypothermia in waking subjects. PLoS One 2015;10:e0129709.

74. Logan A, Sangkachand P, Funk M. Optimal management of shivering during therapeutic hypothermia after cardiac arrest. Crit Care Nurse 2011;31:e18-30.

75. Lascarrou JB, Le Gouge A, Dimet J, Lacherade JC, Martin-Lefèvre L, Fiancette M, et al. Neuromuscular blockade during therapeutic hypothermia after cardiac arrest: observational study of neurological and infectious outcomes. Resuscitation 2014;85:1257-62.

76. Salciccioli JD, Cocchi MN, Rittenberger JC, Peberdy MA, Ornato JP, Abella BS, et al. Continuous neuromuscular blockade is associated with decreased mortality in post-cardiac arrest patients. Resuscitation 2013;84:1728-33.

77. Lee DH, Lee BK, Jeung KW, Jung YH, Cho YS, Youn CS, et al. Neuromuscular blockade requirement is associated with good neurologic outcome in cardiac arrest survivors treated with tar- geted temperature management. J Crit Care 2017;40:218-24.

78. Lee BK, Cho IS, Oh JS, Choi WJ, Wee JH, Kim CS, et al. Continuous neuromuscular blockade infusion for out-of-hospital cardiac arrest patients treated with targeted temperature management: a multicenter randomized controlled trial. PLoS One 2018;13:e0209327.

79. May TL, Riker RR, Fraser GL, Hirsch KG, Agarwal S, Duarte C, et al. Variation in sedation and neuromuscular blockade regimens on outcome after cardiac arrest. Crit Care Med 2018; 46:e975-80.

80. Peberdy MA, Callaway CW, Neumar RW, Geocadin RG, Zimmerman JL, Donnino M, et al. Part 9: post-cardiac arrest care. 2010 American Heart Association guidelines for cardiopulmonary resuscitation and emergency cardiovascular care. Circulation 2010;122(18 Suppl3):S768-86.

81. Weng Y, Sun S. Therapeutic hypothermia after cardiac arrest in adults: mechanism of neuroprotection, phases of hypothermia, and methods of cooling. Crit Care Clin 2012;28:231-43.

82. Dankiewicz J, Nielsen N, Linder A, Kuiper M, Wise MP, Cronberg $\mathrm{T}$, et al. Infectious complications after out-of-hospital cardiac arrest: a comparison between two target temperatures. Resuscitation 2017;113:70-6.

83. Glover GW, Thomas RM, Vamvakas G, Al-Subaie N, Cranshaw $\mathrm{J}$, Walden A, et al. Intravascular versus surface cooling for targeted temperature management after out-of-hospital cardiac arrest: an analysis of the TTM trial data. Crit Care 2016;20:381.

84. Fisher RS, van Emde Boas W, Blume W, Elger C, Genton P, Lee $\mathrm{P}$, et al. Epileptic seizures and epilepsy: definitions proposed by the International League Against Epilepsy (ILAE) and the International Bureau for Epilepsy (IBE). Epilepsia 2005;46:4702.

85. Nielsen N, Sunde K, Hovdenes J, Riker RR, Rubertsson S, Stammet $\mathrm{P}$, et al. Adverse events and their relation to mortality in out-of-hospital cardiac arrest patients treated with therapeutic hypothermia. Crit Care Med 2011;39:57-64.

86. Abend NS, Topjian A, Ichord R, Herman ST, Helfaer M, Donnelly $\mathrm{M}$, et al. Electroencephalographic monitoring during hypothermia after pediatric cardiac arrest. Neurology 2009;72: 1931-40.

87. Rittenberger JC, Popescu A, Brenner RP, Guyette FX, Callaway CW. Frequency and timing of nonconvulsive status epilepticus in comatose post-cardiac arrest subjects treated with hypothermia. Neurocrit Care 2012;16:114-22.

88. Rossetti AO, Urbano LA, Delodder F, Kaplan PW, Oddo M. Prognostic value of continuous EEG monitoring during therapeutic hypothermia after cardiac arrest. Crit Care 2010; 14:R173. 
89. Sunde K, Pytte M, Jacobsen D, Mangschau A, Jensen LP, Smedsrud C, et al. Implementation of a standardised treatment protocol for post resuscitation care after out-of-hospital cardiac arrest. Resuscitation 2007;73:29-39.

90. Rittenberger JC, Friess S, Polderman KH. Emergency neurological life support: resuscitation following cardiac arrest. Neurocrit Care 2015;23 Suppl 2:S119-28.

91. Egawa S, Hifumi T, Kawakita K, Manabe A, Nakashima R, Matsumura $\mathrm{H}$, et al. Clinical characteristics of non-convulsive status epilepticus diagnosed by simplified continuous electroencephalogram monitoring at an emergency intensive care unit. Acute Med Surg 2016;4:31-7.

92. Brophy GM, Bell R, Claassen J, Alldredge B, Bleck TP, Glauser $T$, et al. Guidelines for the evaluation and management of status epilepticus. Neurocrit Care 2012;17:3-23.

93. Longstreth WT Jr, Fahrenbruch CE, Olsufka M, Walsh TR, Copass MK, Cobb LA. Randomized clinical trial of magnesium, diazepam, or both after out-of-hospital cardiac arrest. Neurology 2002;59:506-14.

94. Monsalve F, Rucabado L, Ruano M, Cuñat J, Lacueva V, Viñuales A. The neurologic effects of thiopental therapy after cardiac arrest. Intensive Care Med 1987;13:244-8.

95. Hofmeijer J, Tjepkema-Cloostermans MC, Blans MJ, Beishuizen A, van Putten MJ. Unstandardized treatment of electroencephalographic status epilepticus does not improve outcome of comatose patients after cardiac arrest. Front Neurol 2014;5:39.

96. Crepeau AZ, Rabinstein AA, Fugate JE, Mandrekar J, Wijdicks EF, White RD, et al. Continuous EEG in therapeutic hypothermia after cardiac arrest: prognostic and clinical value. Neurology 2013;80:339-44.

97. Knight WA, Hart KW, Adeoye OM, Bonomo JB, Keegan SP, Ficker DM, et al. The incidence of seizures in patients undergoing therapeutic hypothermia after resuscitation from cardiac arrest. Epilepsy Res 2013;106:396-402.

98. Kern KB, Hilwig RW, Rhee KH, Berg RA. Myocardial dysfunction after resuscitation from cardiac arrest: an example of global myocardial stunning. J Am Coll Cardiol 1996;28:232-40.

99. Oksanen T, Skrifvars M, Wilkman E, Tierala I, Pettilä V, Varpula T. Postresuscitation hemodynamics during therapeutic hypothermia after out-of-hospital cardiac arrest with ventricular fibrillation: a retrospective study. Resuscitation 2014;85:101824.

100. Laurent I, Monchi M, Chiche JD, Joly LM, Spaulding C, Bourgeois B, et al. Reversible myocardial dysfunction in survivors of out-of-hospital cardiac arrest. J Am Coll Cardiol 2002;40: 2110-6.

101. Ruiz-Bailén M, Aguayo de Hoyos E, Ruiz-Navarro S,
Díaz-Castellanos MA, Rucabado-Aguilar L, Gómez-Jiménez FJ, et al. Reversible myocardial dysfunction after cardiopulmonary resuscitation. Resuscitation 2005;66:175-81.

102. Ameloot K, Meex I, Genbrugge C, Jans F, Boer W, Verhaert D, et al. Hemodynamic targets during therapeutic hypothermia after cardiac arrest: a prospective observational study. Resuscitation 2015;91:56-62.

103. Kilgannon JH, Roberts BW, Jones AE, Mittal N, Cohen E, Mitchell J, et al. Arterial blood pressure and neurologic outcome after resuscitation from cardiac arrest. Crit Care Med 2014;42:2083-91.

104. Müllner M, Sterz F, Binder M, Hellwagner K, Meron G, Herkner $\mathrm{H}$, et al. Arterial blood pressure after human cardiac arrest and neurological recovery. Stroke 1996;27:59-62.

105. Young MN, Hollenbeck RD, Pollock JS, Giuseffi JL, Wang L, Harrell FE, et al. Higher achieved mean arterial pressure during therapeutic hypothermia is not associated with neurologically intact survival following cardiac arrest. Resuscitation 2015;88: 158-64.

106. Gaieski DF, Band RA, Abella BS, Neumar RW, Fuchs BD, Kolansky DM, et al. Early goal-directed hemodynamic optimization combined with therapeutic hypothermia in comatose survivors of out-of-hospital cardiac arrest. Resuscitation 2009;80: 418-24.

107. Hifumi T, Kawakita K, Yoda T, Okazaki T, Kuroda Y. Association of brain metabolites with blood lactate and glucose levels with respect to neurological outcomes after out-of-hospital cardiac arrest: a preliminary microdialysis study. Resuscitation 2017;110:26-31.

108. Sekhon MS, Griesdale DE, Ainslie PN, Gooderham P, Foster $\mathrm{D}$, Czosnyka $\mathrm{M}$, et al. Intracranial pressure and compliance in hypoxic ischemic brain injury patients after cardiac arrest. Resuscitation 2019; 141:96-103.

109. Sakabe T, Tateishi A, Miyauchi Y, Maekawa T, Matsumoto M, Tsutsui $\mathrm{T}$, et al. Intracranial pressure following cardiopulmonary resuscitation. Intensive Care Med 1987;13:256-9.

110. Krep H, Böttiger BW, Bock C, Kerskens CM, Radermacher B, Fischer M, et al. Time course of circulatory and metabolic recovery of cat brain after cardiac arrest assessed by perfusionand diffusion-weighted imaging and MR-spectroscopy. Resuscitation 2003;58:337-48.

111. van den Brule JM, Vinke E, van Loon LM, van der Hoeven JG, Hoedemaekers CW. Middle cerebral artery flow, the critical closing pressure, and the optimal mean arterial pressure in comatose cardiac arrest survivors: an observational study. Resuscitation 2017;110:85-9.

112. Sundgreen C, Larsen FS, Herzog TM, Knudsen GM, Boes- 
gaard S, Aldershvile J. Autoregulation of cerebral blood flow in patients resuscitated from cardiac arrest. Stroke 2001;32:12832.

113. Beylin ME, Perman SM, Abella BS, Leary M, Shofer FS, Grossestreuer AV, et al. Higher mean arterial pressure with or without vasoactive agents is associated with increased survival and better neurological outcomes in comatose survivors of cardiac arrest. Intensive Care Med 2013;39:1981-8.

114. Grand J, Hassager C, Winther-Jensen M, Rundgren M, Friberg $\mathrm{H}$, Horn J, et al. Mean arterial pressure during targeted temperature management and renal function after out-of-hospital cardiac arrest. J Crit Care 2019;50:234-41.

115. Janiczek JA, Winger DG, Coppler P, Sabedra AR, Murray H, Pinsky MR, et al. Hemodynamic resuscitation characteristics associated with improved survival and shock resolution after cardiac arrest. Shock 2016;45:613-9.

116. Sekhon MS, Gooderham P, Menon DK, Brasher PMA, Foster D, Cardim D, et al. The burden of brain hypoxia and optimal mean arterial pressure in patients with hypoxic ischemic brain injury after cardiac arrest. Crit Care Med 2019;47:960-9.

117. Jakkula P, Pettilä V, Skrifvars MB, Hästbacka J, Loisa P, Tiainen $\mathrm{M}$, et al. Targeting low-normal or high-normal mean arterial pressure after cardiac arrest and resuscitation: a randomised pilot trial. Intensive Care Med 2018;44:2091-101.

118. Caironi P, Tognoni G, Masson S, Fumagalli R, Pesenti A, Romero $\mathrm{M}$, et al. Albumin replacement in patients with severe sepsis or septic shock. N Engl J Med 2014;370:1412-21.

119. Rab T, Kern KB, Tamis-Holland JE, Henry TD, McDaniel M, Dickert NW, et al. Cardiac arrest: a treatment algorithm for emergent invasive cardiac procedures in the resuscitated comatose patient. J Am Coll Cardiol 2015;66:62-73.

120. Post H, Schmitto JD, Steendijk P, Christoph J, Holland R, Wachter R, et al. Cardiac function during mild hypothermia in pigs: increased inotropy at the expense of diastolic dysfunction. Acta Physiol (Oxf) 2010;199:43-52.

121. Thomsen JH, Hassager C, Bro-Jeppesen J, Søholm H, Nielsen $\mathrm{N}$, Wanscher $\mathrm{M}$, et al. Sinus bradycardia during hypothermia in comatose survivors of out-of-hospital cardiac arrest: a new early marker of favorable outcome? Resuscitation 2015;89:36-42.

122. Thomsen JH, Nielsen N, Hassager C, Wanscher M, Pehrson S, Køber L, et al. Bradycardia during targeted temperature management: an early marker of lower mortality and favorable neurologic outcome in comatose out-of-hospital cardiac arrest patients. Crit Care Med 2016;44:308-18.

123. Inoue A, Hifumi T, Yonemoto N, Kuroda Y, Kawakita K, Sawano $\mathrm{H}$, et al. The impact of heart rate response during 48-hour rewarming phase of therapeutic hypothermia on neurologic outcomes in out-of-hospital cardiac arrest patients. Crit Care Med 2018;46:e881-8.

124. Kilgannon JH, Jones AE, Shapiro NI, Angelos MG, Milcarek B, Hunter $\mathrm{K}$, et al. Association between arterial hyperoxia following resuscitation from cardiac arrest and in-hospital mortality. JAMA 2010;303:2165-71.

125. Bellomo R, Bailey M, Eastwood GM, Nichol A, Pilcher D, Hart GK, et al. Arterial hyperoxia and in-hospital mortality after resuscitation from cardiac arrest. Crit Care 2011;15:R90.

126. Wang HE, Prince DK, Drennan IR, Grunau B, Carlbom DJ, Johnson N, et al. Post-resuscitation arterial oxygen and carbon dioxide and outcomes after out-of-hospital cardiac arrest. Resuscitation 2017;120:113-8.

127. Sutherasan Y, Peñuelas O, Muriel A, Vargas M, Frutos-Vivar F, Brunetti I, et al. Management and outcome of mechanically ventilated patients after cardiac arrest. Crit Care 2015;19:215.

128. Videtta W, Villarejo F, Cohen M, Domeniconi G, Santa Cruz $\mathrm{R}$, Pinillos $\mathrm{O}$, et al. Effects of positive end-expiratory pressure on intracranial pressure and cerebral perfusion pressure. Acta Neurochir Suppl 2002;81:93-7.

129. Janz DR, Hollenbeck RD, Pollock JS, McPherson JA, Rice TW. Hyperoxia is associated with increased mortality in patients treated with mild therapeutic hypothermia after sudden cardiac arrest. Crit Care Med 2012;40:3135-9.

130. Elmer J, Scutella M, Pullalarevu R, Wang B, Vaghasia N, Trzeciak $\mathrm{S}$, et al. The association between hyperoxia and patient outcomes after cardiac arrest: analysis of a high-resolution database. Intensive Care Med 2015;41:49-57.

131. Helmerhorst HJ, Roos-Blom MJ, van Westerloo DJ, de Jonge E. Association between arterial hyperoxia and outcome in subsets of critical illness: a systematic review, meta-analysis, and meta-regression of cohort studies. Crit Care Med 2015;43: 1508-19.

132. Damiani E, Adrario E, Girardis M, Romano R, Pelaia P, Singer $\mathrm{M}$, et al. Arterial hyperoxia and mortality in critically ill patients: a systematic review and meta-analysis. Crit Care 2014; 18:711.

133. Wang $\mathrm{CH}$, Chang WT, Huang $\mathrm{CH}$, Tsai MS, Yu PH, Wang AY, et al. The effect of hyperoxia on survival following adult cardiac arrest: a systematic review and meta-analysis of observational studies. Resuscitation 2014;85:1142-8.

134. Vaahersalo J, Bendel S, Reinikainen M, Kurola J, Tiainen M, Raj R, et al. Arterial blood gas tensions after resuscitation from out-of-hospital cardiac arrest: associations with long-term neurologic outcome. Crit Care Med 2014;42:1463-70.

135. Buunk G, van der Hoeven JG, Meinders AE. Cerebrovascular reactivity in comatose patients resuscitated from a cardiac ar- 
rest. Stroke 1997;28:1569-73.

136. Bisschops LL, Hoedemaekers CW, Simons KS, van der Hoeven JG. Preserved metabolic coupling and cerebrovascular reactivity during mild hypothermia after cardiac arrest. Crit Care Med 2010;38:1542-7.

137. Curley G, Kavanagh BP, Laffey JG. Hypocapnia and the injured brain: more harm than benefit. Crit Care Med 2010; 38:1348-59.

138. Schneider AG, Eastwood GM, Bellomo R, Bailey M, Lipcsey $\mathrm{M}$, Pilcher D, et al. Arterial carbon dioxide tension and outcome in patients admitted to the intensive care unit after cardiac arrest. Resuscitation 2013;84:927-34.

139. Lee BK, Jeung KW, Lee HY, Lee SJ, Jung YH, Lee WK, et al. Association between mean arterial blood gas tension and outcome in cardiac arrest patients treated with therapeutic hypothermia. Am J Emerg Med 2014;32:55-60.

140. Roberts BW, Kilgannon JH, Chansky ME, Mittal N, Wooden J, Trzeciak S. Association between postresuscitation partial pressure of arterial carbon dioxide and neurological outcome in patients with post-cardiac arrest syndrome. Circulation 2013; 127:2107-13.

141. Eastwood GM, Schneider AG, Suzuki S, Peck L, Young H, Tanaka A, et al. Targeted therapeutic mild hypercapnia after cardiac arrest: a phase II multi-centre randomised controlled trial (the CCC trial). Resuscitation 2016;104:83-90.

142. Daviaud F, Dumas F, Demars N, Geri G, Bouglé A, MorichauBeauchant $T$, et al. Blood glucose level and outcome after cardiac arrest: insights from a large registry in the hypothermia era. Intensive Care Med 2014;40:855-62.

143. Lee BK, Lee HY, Jeung KW, Jung YH, Lee GS, You Y. Association of blood glucose variability with outcomes in comatose cardiac arrest survivors treated with therapeutic hypothermia. Am J Emerg Med 2013;31:566-72.

144. Cueni-Villoz N, Devigili A, Delodder F, Cianferoni S, Feihl F, Rossetti AO, et al. Increased blood glucose variability during therapeutic hypothermia and outcome after cardiac arrest. Crit Care Med 2011;39:2225-31.

145. Hifumi T, Inoue A, Kokubu N, Hase M, Yonemoto N, Kuroda $\mathrm{Y}$, et al. Association between rewarming duration and neuro- logical outcome in out-of-hospital cardiac arrest patients receiving therapeutic hypothermia. Resuscitation 2020;146:1707.

146. The Quality Standards Subcommittee of the American Academy of Neurology. Practice parameters for determining brain death in adults (summary statement). Neurology 1995; 45:1012-4.

147. Sandroni C, Cariou A, Cavallaro F, Cronberg T, Friberg H, Hoedemaekers C, et al. Prognostication in comatose survivors of cardiac arrest: an advisory statement from the European Resuscitation Council and the European Society of Intensive Care Medicine. Resuscitation 2014;85:1779-89.

148. Oddo M, Sandroni C, Citerio G, Miroz JP, Horn J, Rundgren $\mathrm{M}$, et al. Quantitative versus standard pupillary light reflex for early prognostication in comatose cardiac arrest patients: an international prospective multicenter double-blinded study. Intensive Care Med 2018;44:2102-11.

149. Riker RR, Sawyer ME, Fischman VG, May T, Lord C, Eldridge A, et al. Neurological pupil index and pupillary light reflex by pupillometry predict outcome early after cardiac arrest. Neurocrit Care 2020;32:152-61.

150. Tamura T, Namiki J, Sugawara Y, Sekine K, Yo K, Kanaya T, et al. Quantitative assessment of pupillary light reflex for early prediction of outcomes after out-of-hospital cardiac arrest: a multicentre prospective observational study. Resuscitation 2018;131:108-13.

151. Ruijter BJ, Tjepkema-Cloostermans MC, Tromp SC, van den Bergh WM, Foudraine NA, Kornips FHM, et al. Early electroencephalography for outcome prediction of postanoxic coma: a prospective cohort study. Ann Neurol 2019;86:203-14.

152. May TL, Ruthazer R, Riker RR, Friberg H, Patel N, Soreide E, et al. Early withdrawal of life support after resuscitation from cardiac arrest is common and may result in additional deaths. Resuscitation 2019;139:308-13.

153. Elmer J, Torres C, Aufderheide TP, Austin MA, Callaway CW, Golan E, et al. Association of early withdrawal of life-sustaining therapy for perceived neurological prognosis with mortality after cardiac arrest. Resuscitation 2016;102:127-35. 